\title{
OPTIMIZATION aNd Validation OF THE SOLID-LIQUID EXTRACTION Techilque for Determination of Picloram in SoIls by High Performance Liquid Chromatography ${ }^{1}$
}

\author{
Otimização e Validação da Técnica Extração Sólido-Líquido para a Determinação do Picloram \\ em Solos por Cromatografia Líquida de Alta Eficiência
}

\author{
ASSIS, E.C. ${ }^{2}$, SILVA, A.A. ${ }^{3}$, BARBOSA, L.C. ${ }^{4}$, QUEIROZ, M.E.L.R. ${ }^{4}$, D’ANTONINO, L. $^{5}$ and \\ GONÇALVES, V.A. ${ }^{\circ}$
}

\begin{abstract}
The objective of this study was to optimize and validate the solid-liquid extraction (ESL) technique for determination of picloram residues in soil samples. At the optimization stage, the optimal conditions for extraction of soil samples were determined using univariate analysis. Ratio soil/solution extraction, type and time of agitation, ionic strength and $\mathrm{pH}$ of extraction solution were evaluated. Based on the optimized parameters, the following method of extraction and analysis of picloram was developed: weigh $2.00 \mathrm{~g}$ of soil dried and sieved through a sieve mesh of $2.0 \mathrm{~mm}$ pore, add $20.0 \mathrm{~mL}$ of $\mathrm{KCl}$ concentration of $0.5 \mathrm{~mol} \mathrm{~L}^{-1}$, shake the bottle in the vortex for 10 seconds to form suspension and adjust to $\mathrm{pH} 7.00$, with alkaline $\mathrm{KOH} 0.1 \mathrm{~mol} \mathrm{~L}^{-1}$. Homogenate the system in a shaker system for 60 minutes and then let it stand for 10 minutes. The bottles are centrifuged for 10 minutes at 3,500 rpm. After the settlement of the soil particles and cleaning of the supernatant extract, an aliquot is withdrawn and analyzed by high performance liquid chromatography. The optimized method was validated by determining the selectivity, linearity, detection and quantification limits, precision and accuracy. The ESL methodology was efficient for analysis of residues of the pesticides studied, with percentages of recovery above 90\%. The limits of detection and quantification were 20.0 and $66.0 \mathrm{mg} \mathrm{kg}^{-1}$ soil for the PVA, and 40.0 and $132.0 \mathrm{mg} \mathrm{kg}^{-1} \mathrm{soil} \mathrm{for}^{-}$ the VLA. The coefficients of variation (CV) were equal to 2.32 and 2.69 for PVA and TH soils, respectively. The methodology resulted in low organic solvent consumption and cleaner extracts, as well as no purification steps for chromatographic analysis were required. The parameters evaluated in the validation process indicated that the ESL methodology is efficient for the extraction of picloram residues in soils, with low limits of detection and quantification.
\end{abstract}

Keywords: ESL, testing, waste, herbicide.

\begin{abstract}
RESUMO - O objetivo deste trabalho foi otimizar e validar a técnica extração sólido-líquido (ESL) para a determinação de residuos do herbicida picloram em amostras de solos. Na etapa de otimização, as condições ideais para extração em amostras de solo foram determinadas de forma univariada. Foram avaliados a proporção solo/solução extratora, o tipo e tempo de agitação, a força iônica e o pH da solução extratora. A partir dos parâmetros otimizados, a seguinte metodologia de extração e análise do picloram foi desenvolvida: pesar 2,00 g de solo seco ao ar e passado por uma peneira de malha de 2,0 mm de poro, adicionar 20,0 mL de solução de $\mathrm{KCl}$ na concentração de 0,5 mol $\mathrm{L}^{-1}$, agitaro frasco em agitador vortex por 10 segundos para a formação da suspensão e ajustar o pH desta para

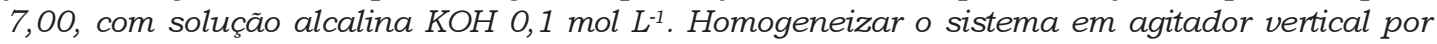
60 minutos e, posteriormente, deixar em repouso por 10 minutos. Em seguida, os frascos são centrifugados por 10 minutos a $3.500 \mathrm{rpm}$. Após decantação das particulas do solo e limpeza do extrato sobrenadante, uma aliquota é retirada e encaminhada à análise por cromatografia liquida de alta eficiência. O método otimizado foi validado determinando-se a seletividade, linearidade, limites de detecção e quantificação, precisão e exatidão. A metodologia ESL mostrou-se eficiente para análise
\end{abstract}

1 Recebido para publicação em 10.2.2011 e aprovado em 17.4.2011.

2 Licenciado em Química, M.Sc., <emanuelagroufv@hotmail.com>; ${ }^{3}$ D.Sc., Professor Associado, Dep. de Fitotecnia, Universidade Federal de Viçosa - DFT/UFV; ${ }^{4}$ D.Sc., Professor Associado, Dep. de Química -DEQ/UFV; ${ }^{5}$ Engo-Agro ${ }^{2}$, D.Sc., DFT/UFV; ${ }^{5}$ Acadêmico de Agronomia - UFV.

Planta Daninha, Viçosa-MG, v. 29, n. 3, p. 683-696, 2011 
dos resíduos do agrotóxico estudado, com porcentagens de recuperação acima de 90\%. Ela apresentou limites de detecção e quantificação iguais a 20, 0 e 66,0 $\mu \mathrm{g} \mathrm{kg}^{-1}$ para o solo PVA, assim como 40,0 e $132,0 \mu \mathrm{g} \mathrm{kg}^{1}$ para o solo LVA. Os coeficientes de variação (CV) foram de 2, 32 e 2, 69 para os solos PVA e LVA, respectivamente. A metodologia apresentou baixo consumo de solventes orgânicos e extratos limpos, não necessitando de etapas de purificação para análise cromatográfica. Os parâmetros avaliados, no processo de validação, indicaram que a metodologia ESL é eficiente para extração dos residuos de picloram nos solos estudados, apresentando baixos limites de detecção e quantificação.

Palavras-chave: ESL, análise, resíduos, herbicida.

\section{INTRODUCTION}

One of the main characteristics of the Brazilian cattle industry is the wide availability of natural pastures, which allows the meat and milk production competitively in terms of quality and a lower production cost (Santos et al., 2006). However, most of these pastures have some stage of degradation. This is happening due to improper handling, loss of soil fertility, lack of fertilization and also the lack of expert assistance (Pires, 2006).

Pasture degradation favors the emergence of many weed species. These plants compete for growth factors such as water, macro and micronutrients, carbon dioxide and light. This competition is very hard because the weeds have innate characteristics that make them more efficient in relation to crops. These plants produce quantities of uneven seed germination, present dormancy, are very easy to spread and reproduce themselves by vegetative parts. Many weeds also release allelopathic substances in the soil, which occurs for a few crops (Demuner et al., 2005). These substances can inhibit the development of other species in theirs vicinity, thereby facilitating their development (Silva \& Silva, 2007).

One of the main herbicides registered in Brazil for combating weeds in pastures is the picloram acid (4-amino-3, 5, 6-trichloro-2Pyridine - Figure 1). This herbicide is widely used alone or in combination to control arboreal, shrubby and subshrubby dicot weeds (Rodrigues \& Almeida, 2005).

Picloram is a pyridine herbicide which acts as a plant growth regulator, mimicking either natural auxin or hindolylacetic acid hormones, inhibiting protein synthesis. It is considered an anionic herbicide by nature. Picloram is toxic to broad-leaved plants and presents selectivity in grasses cultures (D'Antonino et al., 2009), being the most persistent herbicide from the pyridines family (Santos et al., 2007). It presents long persistence in soil, with half-life of 90 days (Rodrigues \& Almeida, 2005), and can be found up to two or three years after the application in total area (Deubert \& Corte-Real, 1986). Due to high water solubility (430 $\mathrm{mg} \mathrm{L}^{-1}$ ) and long persistence, it is considered an herbicide with a high potential for groundwater contamination (Singh \& Singh, 2007, Inoue et al., 2003).

It is estimated that $1-3 \%$ of the total applied herbicide will reach the site of action (Lourencetti et al., 2008). Most of that total hits the ground and will be subject to chemical, physical and biological agents, due to interaction with this matrix. These processes affect their persistence, chemical and microbiological degradation, which consequently affect their mobility, adsorption, plant uptake, volatilization, drift, runoff and leaching (Lourencetti et al., 2008, Silva \& Silva, 2007).

The performance evaluation of pesticides in soils is presented as an alternative to prevent contamination of successive crops, surface water and groundwater as well.

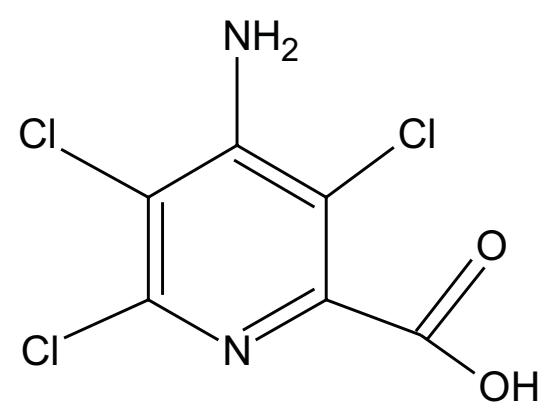

Figure 1 - Picloram: structural formula. 
The development and application of methodologies for the determination of pesticides in the soil face some obstacles, such as the concentration of these substances after application, which can be low or high, and the different types of interaction between these molecules and the soil colloids, which can form weak or strong interactions. Other factors that may alter the effectiveness of a method are connected to the properties of soils $\mathrm{pH}$, texture and mineralogy, organic matter content and other components in the soil that can be coexctracted (Lourencetti et al., 2008).

There are various methods of extraction and analysis for picloram herbicide in soil and water found in the literature. In general, the chromatographic techniques are the most used. (Cheng, 1969, 1971; McCaall et al., 1972; Biggar \& Cheung, 1973; McKone, et al., 1974; Wells et al., 1984, 1987; Bovey \& Richardson, 1991; Krzyszowska et al., 1994; Lavy et al., 1996; Bruner et al., 1996; Tan et al., 1996; Wells \& Yu, 2000; Celis et al., 2002, 2005). Most of these studies were conducted in temperate soils. These soils, which somehow are relatively young and less weathered, have some characteristics different from those more weathered soils such as in Brazil's tropical climate.

The aim of this study was to adapt, optimize and validate the technique of solid-liquid extraction proposed by Cheng (1969) and the analysis methodology proposed by Krzyszowska et al. (1994) for the determination of herbicides in Brazilian soils by liquid chromatography with high efficiency.

\section{MATERIALS AND METHODS}

The analytical pattern of picloram $(98.5 \%$ purity) was obtained by ChemService (West Chester, PA). Stock solution (100 mg L-1) and working solutions at different concentrations were prepared in acetic acid solution $25 \%$ and stored in dark place at room temperature. Acetic acid (Vetec/HPLC), acetonitrile (Vetec/ $\mathrm{HPLC}$ ) and reagents such as $\mathrm{KCl}, \mathrm{NaCl}, \mathrm{CaCl} 2$, $\mathrm{HCl}$ and $\mathrm{NaOH}$ were all of analytical grade for analysis.

Red-Yellow Acrisol (PVA) and Red-Yellow Latosol (LVA) soil samples were collected in depth from 00 to $20 \mathrm{~cm}$ in degraded pastures without herbicide application in the region of Viçosa, MG. These soils were chosen because of their differences related to both the organic matter content and $\mathrm{pH}$. After the collection, the samples were sieved through a sieve mesh of $4 \mathrm{~mm}$ and stored in $1 \mathrm{~m}^{3}$ capacitypolyethylene boxes. For the optimization and validation of the extraction technique, $500 \mathrm{~g}$ of each soil (air dried soil - TFSA) were passed through a sieve mesh of $2.0 \mathrm{~mm}$ and stored in plastic bags until the start the works. These samples were chemically and physically characterized (Table 1).

PVA soil samples were weighed on an analytical balance (accurate to $0.0001 \mathrm{~g}$ ) in plastic tubes with screw caps and conical bottom. The mass of the soil used in the work done by Cheng (1969) and Krzyszowska et al. (1994) was $100.00 \mathrm{~g}$. Aiming to reduction of all the parameters proposed by these works, it was adopted the mass of $2.00 \mathrm{~g}$ of soil.

Table 1 - Physical-chemical and textural classification of soil samples used in the experiment. Viçosa, MG

\begin{tabular}{|c|c|c|c|c|c|c|c|c|c|c|}
\hline \multicolumn{11}{|c|}{ Particle size analysis } \\
\hline Soil & \multicolumn{2}{|c|}{ Clay } & Silt & \multicolumn{2}{|l|}{ Fine sand } & Grit & \multicolumn{4}{|c|}{ Texture classification } \\
\hline PVA & \multicolumn{2}{|l|}{26} & 16 & \multicolumn{2}{|l|}{29} & 29 & \multicolumn{4}{|c|}{ Sandy Clay Loam } \\
\hline LVA & \multicolumn{2}{|l|}{35} & 21 & \multicolumn{2}{|l|}{30} & 14 & \multicolumn{4}{|c|}{ Sandy Clay } \\
\hline \multicolumn{11}{|c|}{ Chemical analysis } \\
\hline \multirow[t]{2}{*}{ Soil } & $\mathrm{pH}$ & $\mathrm{P}$ & $\mathrm{K}^{+}$ & $\mathrm{Ca}^{++}$ & $\mathrm{Mg}^{++}$ & $\mathrm{H}+\mathrm{Al}$ & $\begin{array}{l}\text { CTC } \\
\text { total }\end{array}$ & V & $\mathrm{m}$ & $\mathrm{MO}$ \\
\hline & $\left(\mathrm{H}_{2} \mathrm{O}\right)$ & \multicolumn{6}{|c|}{$\left(\mathrm{cmol} \mathrm{dm}^{-2}\right)$} & \multicolumn{2}{|c|}{$(\%)$} & $\left(\right.$ dag kg $\left.^{-1}\right)$ \\
\hline PVA & 4,96 & 12.1 & 61 & 3.2 & 1.6 & 4.79 & 4.96 & 51 & 0 & 3.10 \\
\hline LVA & 6,33 & 124.2 & 59 & 12.0 & 6.6 & 3.14 & 18.75 & 86 & 0 & 1.70 \\
\hline
\end{tabular}

Analyses performed in the Viçosa Analytical Laboratory of Soil, according to the methodology of the Brazilian Agricultural Research Corporation - Embrapa (1997). 
These samples were spiked with $0.100 \mathrm{~mL}$ of working solution of concentration equal to $10.0 \mathrm{mg} \mathrm{L}^{-1}$, in order to obtain a final extract concentration of $50.0 \mu \mathrm{g} \mathrm{L}^{-1}$.

After fortification, samples were allowed to rest for an hour, waiting for a greater interaction between the molecules of the herbicide and the soil. Then these samples were subjected to the extraction process and, ultimately, the best conditions for the determination of this herbicide by liquid chromatography were degined.

In the optimization of the extraction technique, some key parameters proposed by Cheng (1969) were evaluated separately, what is called univariate analysis. PVA soil was used during the optimization stage.

The extraction solution proposed by Cheng (1969) consists of a salt solution of $\mathrm{KCl}$ with a concentration of $2.0 \mathrm{~mol} \mathrm{~L}^{-1}$ and $\mathrm{pH}$ equals to 7.00. The soil ratio: extraction solution was $1: 1$, using $100.0 \mathrm{~g}$ of soil and $100.0 \mathrm{~mL}$ of solution. The optimization objective was to reduce the mass of samples and the volume of the extraction solution used in the extraction step, and the waste generated as well. All preliminary tests were triplicate performed.

For the first preliminary test was fixed a mass of $2.00 \mathrm{~g}$ for PVA soil, maintained the concentration of $2.0 \mathrm{~mol} \mathrm{~L}^{-1}$ of $\mathrm{KCl}$ solution, $\mathrm{pH}$ 5.50 (original $\mathrm{pH}$ of the solution prepared in distilled water) and then it varied the soil ratio: extraction solution. It was evaluated three different ratios: 1:2.5, 1:5 and 1:10.

The second measured parameter was the extracting solution concentration. Four different levels were tested: 2.0, 1.0, 0.5 and $0.0 \mathrm{~mol} \mathrm{~L}^{-1}$ of $\mathrm{KCl}$. A mass of $2.00 \mathrm{~g}$ and $\mathrm{pH} 5.50$ were maintained.

The third parameter is related to the extracting solution $\mathrm{pH}$. It was tested eight $\mathrm{pH}$ levels: 1.0, 2.0, 3.0, 4.0, 5.0, 6.0, 7.0 and 8.0. The best results ( $\mathrm{pH} 5.50)$ obtained in the previous evaluation was maintained.

Other evaluated parameters are linked to agitation stage; two types were tested, horizontal agitation (shaker Tecnal TE - 420) and vertical agitation, as well as the agitation time needed to obtain the best extraction percentages, which were 30 and $60 \mathrm{~min}$. After agitation step, the extracts acquired intense orange color and showed to be unsuitable for immediate analysis. As a final step in this process, samples were centrifuged for $10 \mathrm{~min}$ at 3,500 revolutions per minute ( $\mathrm{rpm})$ for settling particles and extract cleaning.

Then, $1.5 \mathrm{~mL}$ of the supernatant extract was withdrawn, transferred to a $5.0 \mathrm{~mL}$ glass syringe with a membrane filter of $0.45 \mu \mathrm{m}$ pore attached to its tip. Extract filtering was made directly on glasses of $1.8 \mathrm{~mL}$ capacity, which were stored in Styrofoam boxes in dark room temperature until the liquid chromatography analysis.

In picloram determination it was used a liquid chromatography apparatus of high efficiency (Shimadzu LC 20AT) equipped with four pumps for solvent output, autosampler (Shimadzu SIL 10AF) with loop of $50 \mu \mathrm{L}, \mathrm{UV}$-vis detector (Shimadzu NTS 20A), column oven (Shimadzu CTO 10ASVP), stainless steel column (Shimadzu VP-ODS Shim-pack $150 \mathrm{~mm} \times 4.6 \mathrm{~mm}$ id) maintained at a constant temperature of $26^{\circ} \mathrm{C}$. The mobile phase consisted of a aqueous mixture of acid acetic $4 \%$ and acetonitrile $(85: 15, \mathrm{v} / \mathrm{v})$ and was eluted in isocratic mode at flow rate equal to $1.2 \mathrm{~mL} \mathrm{~min}^{-1}$. Before the use, the mobile phase was filtered through a Millipore membrane (Bedford, MA, USA) $0.45 \mu \mathrm{m}$. The pesticide detection was performed at $254 \mathrm{~nm}$.

Picloram identification in the extracts was measured by comparing its retention time in the chromatograms of extracts with the retention time of standard solution containing the same active ingredient, analyzed under the same chromatographic conditions.

Quantification was performed by comparison of peak areas found in the analysis with standards prepared in the matrices extract.

The method selectivity was evaluated by comparing chromatograms of extracts obtained from the herbicide free soil samples, known as white, with chromatograms of extracts from the picloram fortified matrix submitted to the optimized procedure.

The proposed method response linearity was determined by injecting extracts of 
spiked samples in increasing concentrations: 2.0, 3.0, 4.0, 5.0, 10.0, 15.0, 20.0, 25.0, 50.0 and $100.0 \mu \mathrm{g} \mathrm{L}^{-1}$. These concentration values were expected for the extract, considering a recovery percentage equal to $100 \%$. The linearity was assessed by linear regression of these calibration curves.

The detection (LD) and quantification (LQ) limits of the method were determined using the method of signal-to-noise ratio in which the lowest concentration detected or measured should be the one where the area is 3 and 10 times respectively, the area of the equipment noise. Soil samples were spiked to obtain extracts in decreasing concentrations of 5.0, 4.0, 3.0, 2.0, and $1.0 \mu \mathrm{g} \mathrm{L}^{-1}$. These extracts were injected until the signal-to-noise ratio to be observed in proportions of 3:1 and $10: 1$.

The precision of the method was estimated by an intralaboratory study, for evaluating the repeatability and intermediate precision.

The method repeatability for picloram residues analysis in Brazilian soils was determined by performing the herbicide extraction from spiked samples, which would present final extract concentrations of $10 \mu \mathrm{g} \mathrm{L}^{-1}$ and $20 \mu \mathrm{g} \mathrm{L}^{-1}$ for PVA and LVA soils, respectively. These values are close to the limits of quantification for each soil, following the optimized procedure, performing seven repetitions to calculate the relative standard deviation (INMETRO, 2003).

The intermediate precision of the method was determined by performing tests in triplicate, for the conditions set. The herbicide extraction from fortified soil samples - which extracts should present concentrations of $10 \mu \mathrm{g} \mathrm{L}^{-1}$ and $20 \mu \mathrm{g} \mathrm{L}^{-1}$ for PVA and LVA soils, respectively - were performed on three different days $\left(1^{\text {st }}, 7^{\text {th }}\right.$ and $30^{\text {th }}$ day). Intermediate precision was evaluated by the recovery percentage, the estimate of standard deviation and the coefficient of variation, determined for each test.

In recovery experiments, picloram was added to soil at concentrations close to 1,2 and 5 times the limit of quantification (LQ) of the method. Thus, tests were performed by extracting the analyte from the soil samples.
The recovery values obtained in the test were used to evaluate the accuracy of the method.

\section{RESULTS AND DISCUSSION}

Chromatography is an analysis technique that allows separation, identification and quantification of organic compounds. In this work, once it considered only one compound of interest, the separation process involved only the distinction between the matrix coextracted compounds and the picloram. In Table 2 are presented the initial parameters for the analysis proposed by Krzyszowska \& Vance (1994), as well as the parameters optimized in this work.

The optimization of a technique aims mainly to reduce time and cost in addition to achieve a greater efficiency. In the analysis optimization process, pointing to reduce the solvent volume and analysis time, some parameters were evaluated and modified. The first was the flow rate of mobile phase. The volume of mobile phase eluted per minute by the column proposed by Krzyszowska \& Vance (1994) meant that the array of substances coextracted from the soil matrix to elute in retention times very close to that of picloram - a fact that hindered the integration and attainment of the area. Another factor was the high pressure generated at the entrance of the column, which, in the medium term, could damage the separation column, reducing its useful life. Therefore, it was chosen to reduce

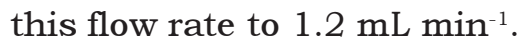

The second and main modified parameter was the mobile phase composition. Three

Table 2 - Conditions for picloram by high performance liquid chromatographic

\begin{tabular}{|l|c|c|}
\hline Mobile Phase & $\begin{array}{c}\text { Acetic acid } \\
\text { solution } 4 \% / \\
\text { acetonitrile* } \\
(95 / 5 \mathrm{v} / \mathrm{v})\end{array}$ & $\begin{array}{c}\text { Acetic acid } \\
\text { solution } 4 \% / \\
\text { acetonitrile } \\
(85 / 15 \mathrm{v} / \mathrm{v})\end{array}$ \\
\hline Flow Rate $\left(\mathrm{mL} \mathrm{min}^{-1}\right)$ & 1.5 & 1.2 \\
\hline Wave length $(\mathrm{nm})$ & 254 & 254 \\
\hline Range of absorbance & 0,01 & 0,01 \\
\hline Retention Time $(\mathrm{min})$ & 17 & 8,10 \\
\hline Loop $(\mu \mathrm{L})$ & 100 & 50 \\
\hline
\end{tabular}

* Conditions proposed by Krzyszowska \& Vance (1994)

** Conditions for this study. 
different ratios were tested: 95:5 v/v, 90:10 $\mathrm{v} / \mathrm{v}$, and $85: 15 \mathrm{v} / \mathrm{v}$ (aqueous solution of acetic acid 4\% and acetonitrile). The mobile phase composition which provided the best peaks separation and decreased the retention time from $17 \mathrm{~min}$ to $8.10 \mathrm{~min}$ was the $85: 15 \mathrm{v} / \mathrm{v}$ ratio. This decrease in retention time was very important, because besides teaking to less time to perform the analysis, smaller volumes of waste were generated for disposal.

Picloram was identified by comparing two chromatograms: one generated by injecting an aqueous solution of acetic acid, 25\% herbicide free - and the other, a standard solution; both were analyzed under the same chromatographic conditions.

Standards and sample chromatographic analysis were performed according to the conditions described in Table 2. Figure 2 shows a chromatogram of a standard solution of picloram at a concentration of $30.0 \mu \mathrm{g} \mathrm{L}^{-1}$, prepared in acetic acid $25 \%$, with a total analysis time of $10 \mathrm{~min}$. Picloram quantification was performed by external standard method. For this, calibration curves were obtained by injecting standard solutions in increasing concentrations ( 1.0 to $100.0 \mu \mathrm{g} \mathrm{L}^{-1}$ ) of picloram, prepared in the soil extracts of active principle free matrices, subject to the optimized extraction method. Calibration curves are shown in Figures 3 and 4.

A coefficient of determination $\left(\mathrm{r}^{2}\right)$ greater than 0.999 is considered evidence of an ideal data fit for the regression line. ANVISA recommends a coefficient of determination equivalent to 0.99 (ANVISA, 2003; Ribani et al., 2004). Therefore, it is observed that the values obtained are higher than 0.99, indicating that there is a linear response (a direct signal/concentration relation) of the detector in the range of 1.0 to $100.0 \mu \mathrm{g} \mathrm{L}^{-1}$ for the studied analyte.

In the process of solid-liquid extraction technique optimization for the determination of picloram in Brazilian soils, the first parameter optimized was the ratio soil: extraction solution. Cheng's idea (1969) was the ratio of $1: 1$, using $100.0 \mathrm{~g}$ of soil to $100.0 \mathrm{~mL}$ of extraction solution. With the main objective of reducing the volume of generated waste, it was adopted a mass of $2.00 \mathrm{~g}$ of soil, because, according to Paula (2007), when working with large masses of soil there is a high extraction of interference substances.

Three different volumes of extraction solution were evaluated (5.0, 10.0 and $20.0 \mathrm{~mL}$ ), producing ratios of $1: 2.5 \mathrm{v} / \mathrm{v}, 1: 5 \mathrm{v} / \mathrm{v}$, and $1: 10$ $\mathrm{v} / \mathrm{v}$, respectively. The extraction solution volume that provided the best recovery percentages was $20.0 \mathrm{~mL}$. This is due to the fact that this volume has favored the better dispersion of soil particles in the solution, favoring the contact between the herbicide molecules and the extracting solution. The recovery percentages obtained are summarized in Table 3.

The second parameter optimized was the extracting solution concentration. Cheng (1969) used a $\mathrm{KCl}$ solution at a concentration of $2 \mathrm{~mol} \mathrm{~L}^{-1}$. This work tested four different concentrations: $0.0,0.5,1.0$ and $2.0 \mathrm{~mol} \mathrm{~L}^{-1}$. The results are presented in Table 4 .

It was observed that, as the extractor concentration increased, the percentage extraction decreased. These results are coincident with those obtained by Farmer \& Aochi (1974). Adding salt to the system changes the ionic strength of the supernatant, the $\mathrm{pH}$, the cation composition of the exchange complex, the thickness of the diffuse double layer, the nature and conformation of organic colloids and the solubility of picloram (Farmer $\&$ Aochi, 1974). Thus, these factors together influence a higher adsorption of molecules of picloram to the soil particles, making their release to the solution more difficult and thus reducing the efficiency of the extraction process.

On the other hand, the lower ionic strength reduced the efficiency of the process of soil settling particles, generating after the agitation step, suspensions of intense yellow color, without any possibility of analysis of these supernatants. The presence of ions in solution favors the soil settling particles due to the insolubility of these in water and the increased interaction between water molecules and these ions by solvation phenomenon.

The third parameter optimized was the type of mechanical agitation and stirring time. 


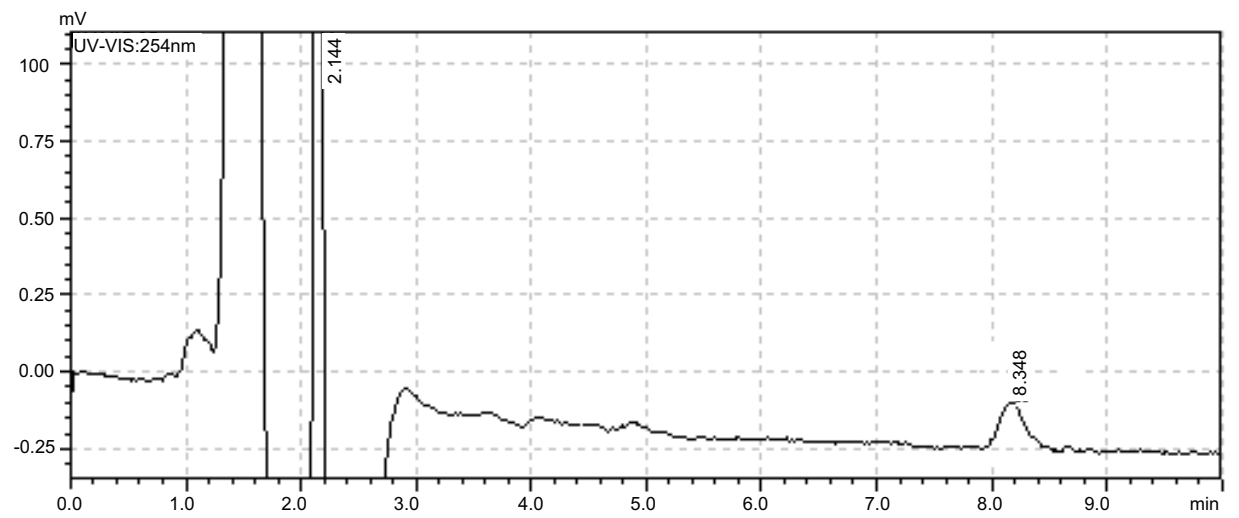

Figure 2 - Detector response in function of time in minutes - chromatogram of a standard solution of $30.0 \mu \mathrm{g} \mathrm{L}^{-1}$ of the active ingredient in a solution of acetic acid $25 \%$, where $t_{R}=8.10$ is the picloram.

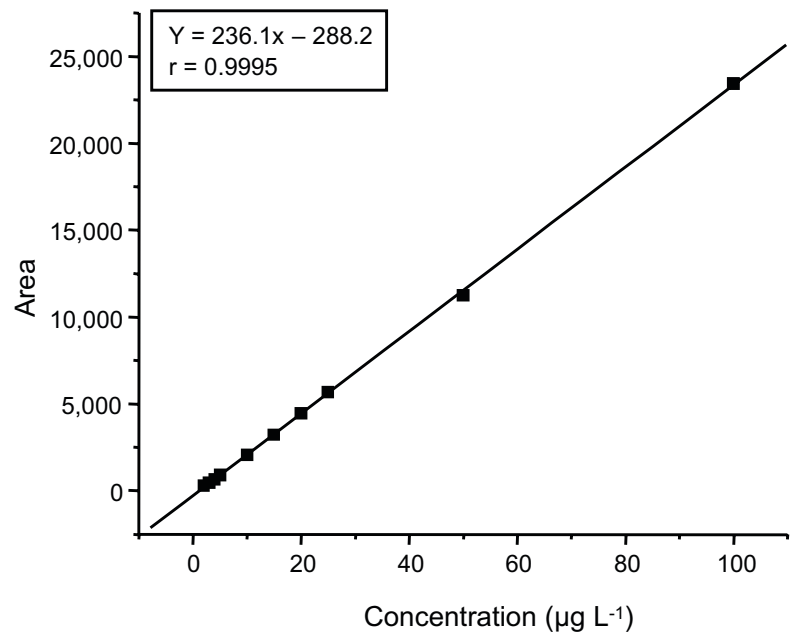

Figure 3 - Picloram calibration curve, prepared in PVA soil extract.

Table 3 - Recovery percentages related to soil ratio: extraction solution

\begin{tabular}{|c|c|}
\hline $\begin{array}{c}\text { Soil ratio: extraction } \\
\text { solution }\end{array}$ & \% recovery \\
\hline $1: 2,5$ & 37.1 \\
\hline $1: 5$ & 46.4 \\
\hline $1: 10$ & 53.9 \\
\hline
\end{tabular}

Table 4 - Recovery percentages in relation to extracting solution concentration

\begin{tabular}{|c|c|}
\hline $\begin{array}{c}\text { Concentration } \mathrm{KCl} \\
\left(\mathrm{mol} \mathrm{L}^{-1}\right)\end{array}$ & \% recovery \\
\hline 2,0 & 52.4 \\
\hline 1,0 & 56.5 \\
\hline 0,5 & 60.8 \\
\hline 0,0 & - \\
\hline
\end{tabular}

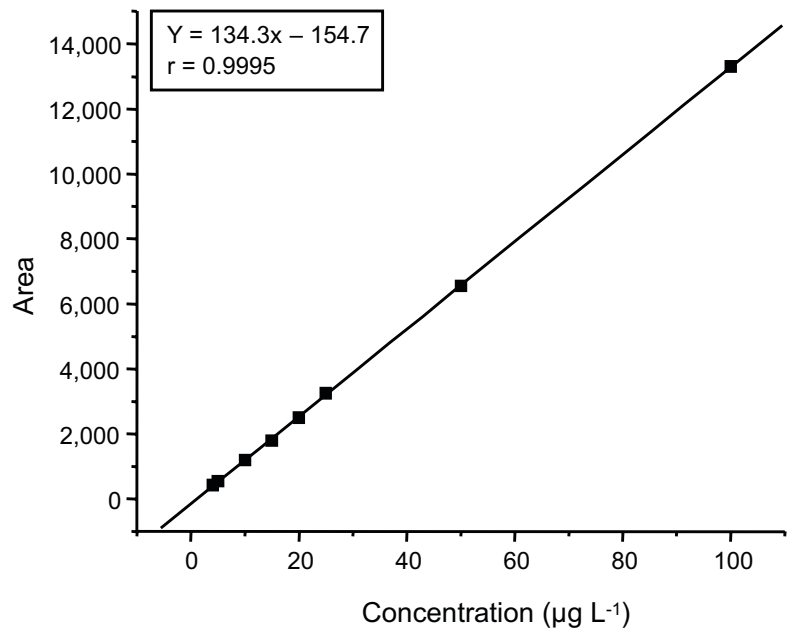

Figure 4 - Picloram calibration curve in LVA soil extract.

Two types of agitation were evaluated: horizontal and vertical. The first, held in the shaker Tecnal TE - 420, did not favor the dispersal of soil particles in the extraction solution. The horizontal circular motion did not allow full engagement between the extraction solution and the soil. The opposite has been achieved during vertical agitation. This type of agitation favored the complete dispersion of soil particles in the midst of extracting solution, which allows greater contact between the solid and liquid phases, allowing a greater release of herbicide molecules to the solution. Two stirring times were tested: 30 and $60 \mathrm{~min}$. The longest time improved the percentages of extraction in around 8\%. Data regarding type parameters and stirring time are shown in Table 5.

Planta Daninha, Viçosa-MG, v. 29, n. 3, p. 683-696, 2011 
Table 5 - Recovery percentages in relation to the type and time of agitation

\begin{tabular}{|c|c|c|c|}
\hline Agitation type & \% recovery & Agitation time (min) & \% recovery \\
\hline Horizontal & 59.8 & 30 & 69.9 \\
\hline Vertical & 70.1 & 60 & 75.4 \\
\hline
\end{tabular}

The last evaluated parameter was the extraction solution $\mathrm{pH}$. According to Cheng (1969), the optimum $\mathrm{pH}$ value for obtaining the best recovery percentages is 7.0 . The herbicide picloram is a weak acid whose anion form predominates in most soils and sediments (Celis et al., 2005). However, in order to confirm the modification proposed and also to understand the behavior of this herbicide in different $\mathrm{pH}$ conditions, we evaluated the extraction of it at different $\mathrm{pH}$ values of extraction solution.

The $\mathrm{pH}$ of extracting solutions was adjusted by adding drops of $\mathrm{KOH}$ and $\mathrm{HCl}$ in concentrations of 0.01 and $0.1 \mathrm{~mol} \mathrm{~L}^{-1}$. The adjustment was made on this basis for this acid not to insert different ions in solution.

The $\mathrm{pH}$ values tested were $1.0,2.0,3.0$, $4.0,5.0,6.0,7.0$, and 8.0. The results are presented in Table 6. The evaluation of picloram extraction percentage in soils using extracting solutions with different $\mathrm{pH}$ values was performed on purpose, because, according to the work proposed by Cheng (1969), the highest extraction rates would be achieved using the extracting solution with $\mathrm{pH}$ at 7.0. In order to confirm this information and obtain a better understanding of the behavior of this herbicide in soils under different $\mathrm{pH}$ conditions, we chose to perform the extraction in other $\mathrm{pH}$ values.

Table 6 - Recovery percentages in relation to extracting solution $\mathrm{pH}$

\begin{tabular}{|c|c|}
\hline $\mathrm{pH}$ & \% recovery \\
\hline 1.0 & - \\
\hline 2.0 & 35.8 \\
\hline 3.0 & 42.3 \\
\hline 4.0 & 52.8 \\
\hline 5.0 & 69.3 \\
\hline 6.0 & 82.4 \\
\hline 7.0 & 95.9 \\
\hline 8.0 & 65.2 \\
\hline
\end{tabular}

It can be observed from the data presented in the table that the $\mathrm{pH}$ value which really favors the achievement of better recovery percentages of picloram is 7.00 . For a $\mathrm{pH}$ equal to 1.0 it was not possible to analyze the extract due to the high concentration of substances coextracted from the soil. The extract had a very yellowish color, which probably is due to the presence of humic acids from organic matter. In alkaline medium, $\mathrm{pH}$ at 8.0, the color of the extract was also yellowish, but less intense, and also because of the presence of humic and fulvic organic matter (Carter, 1993, Tan et al., 1996). This extract was analyzed, while the percentage of extraction found was below the $95.9 \%$ found in $\mathrm{pH}$ at 7.0 . It can be inferred that this reduction is due to the interference of coextracted substances.

In an extraction process, the interactions between herbicide molecules and the matrix must be broken, so that the pesticide moves to the extraction solution. Cheung \& Biggar (1974) studied picloram solubility in water at different temperatures and $\mathrm{pH}$. This work was based on the pKa value for picloram proposed by Hamarker et al. (1968) equal to 4.1, although in literature are reported other pKa values for picloram: $\mathrm{pKa}=4.1$, Hamarker et al. (1968), $\mathrm{pKa}=3.4$, Volk \& Kuo (1970); pKa = 2.3, Celis et al. (2005). In the study performed by Cheung \& Biggar (1974), the four possible kinds of picloram in solutions with different $\mathrm{pH}$ values are elicidated: non ionized picloram, anionic form, cationic form, and dipole form (Figure 5).

'According to the authors, in $\mathrm{pH}$ at 4.2 and 4.8 , respectively $86.3 \%$ and $95.2 \%$ of the herbicide molecules are in anionic form. Moreover the percentages of the protonated species (cationic and dipolar) in $\mathrm{pH}$ at 2.8, 2.0, 1.1 , and 0.2 are respectively $79.9 \%, 96.2 \%$, $99.5 \%$ and 99 9\%. These values explain the results shown in Table 6. At low $\mathrm{pH}$ values, protonated species are more abundant, the adsorption of these species on negatively 


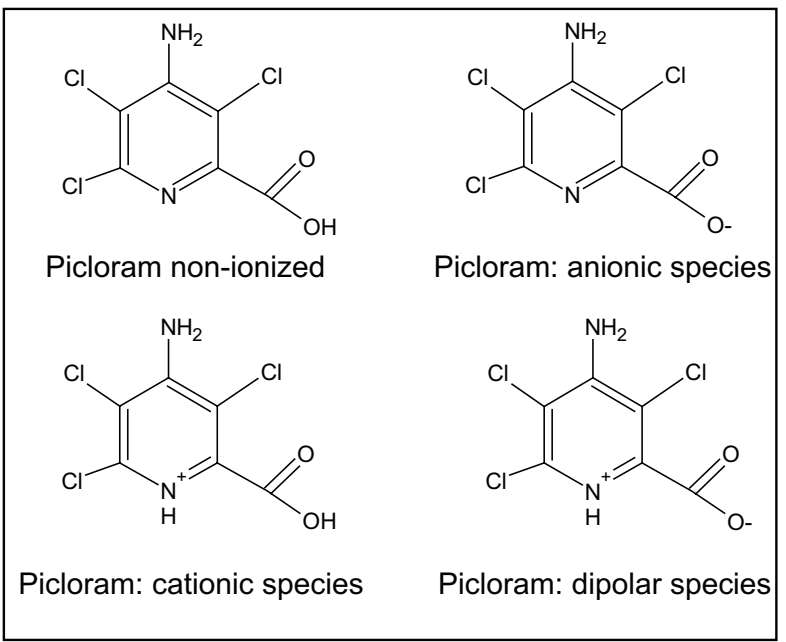

Figure 5 - Possible species of picloram in solution (Cheung \& Biggar, 1974).

charged surfaces of clays and organic colloids from the soil is favored energetically, so they will be more strongly adsorbed to soil colloids, making its extraction more difficult. On the point of in $\mathrm{pH}$ values above 5.0, the anionic species is the predominant one, therefore, due to repulsion between negative charges of soil colloids and the anionic form, the herbicide molecules are present mainly in the soil solution, facilitating the extraction process.

From all the optimized parameters described above, it is proposed as a methodology for extraction and analysis of picloram to weigh $2.00 \mathrm{~g}$ of soil, air dried and sieved through a sieve mesh of $2.0 \mathrm{~mm}$ pore size, add $20,0 \mathrm{~mL}$ of $\mathrm{KCl}$ solution at a concentration of $0.5 \mathrm{~mol} \mathrm{~L}^{-1}$, shake the bottle in vortex for 10 seconds for suspension formation and $\mathrm{pH}$ adjustment to 7.0, with drops of $\mathrm{KOH} 0,1 \mathrm{~mol} \mathrm{~L}^{-1}$ alkaline solution. Afterwards, the system should be shaken in a vertical shaker for $60 \mathrm{~min}$ and then let stand for 10 minutes. Centrifuge the vials for $10 \mathrm{~min}$ at $3,500 \mathrm{rpm}$. After settling of soil particles and extract cleanness, withdraw $1.5 \mathrm{~mL}$ of supernatant and transfer to a $5.0 \mathrm{~mL}$ capacity-glass syringe with a Millipore filter of $0.45 \mu \mathrm{m}$ pore, filtering directly into vials of $1.8 \mathrm{~mL}$ capacity. Thereafter, refer to analysis by liquid chromatography.

The optimized methodology showed good results for the studied soils, resulting in cleaner extracts without the need for clean up or concentration steps besides presenting a small solvent consumption and be a relatively quick and simple technique.

This parameter was evaluated using the ESL of picloram herbicide in the red yellow Acrisol and red yellow Latosol, comparing the chromatograms of extracts obtained from these herbicide free matrices with the compost fortified ones.

Figures 6 and 7 show the chromatograms for Acrisol and Latosol, respectively. It is observed that the chromatograms relating to the white herbicide-free matrices do not have interfering peaks at the same retention time of the analyzed compound, which makes it a selective methodology.

Linearity is the ability of a method to provide results directly proportional to the concentration of the substance in question, within a range of application (Ribani et al., 2004). Initially, it was determined the linearity of the detector response for concentrations from 1.0 to $100.0 \mu \mathrm{g} \mathrm{L}^{-1}$ by injecting standard solutions prepared in matrices extract in which were obtained correlation coefficients of 0.999 for picloram in both soils (Table 3).

For the proposed extraction method linearity analysis, samples from different soils were spiked with increasing concentrations to obtain in the extract concentrations between 1.0 and $100 \mu \mathrm{g} \mathrm{L}^{-1}$, and then subjected to the extraction method. The extracts were then injected and new calibration curves were prepared (Figures 8 and 9).

Obtaining a linear curve means that, in all worked concentration ranges, the percentage of recovery are equivalent. Coefficients of determination obtained are greater than 0.999, featuring an ideal fit to the data for the linear regression, according to ANVISA (2003) and INMETRO (2003).

Compared with the curves obtained by injecting standards prepared in matrices extracts (Table 5), it appears that the angular and linear coefficients have similar values, which show good agreement between the extracts and the sensitivity of the detection system. The use of the curve prepared in the extract helped to eliminate the matrix effect.

The methodology applied to PVA soil samples presents linear response in 

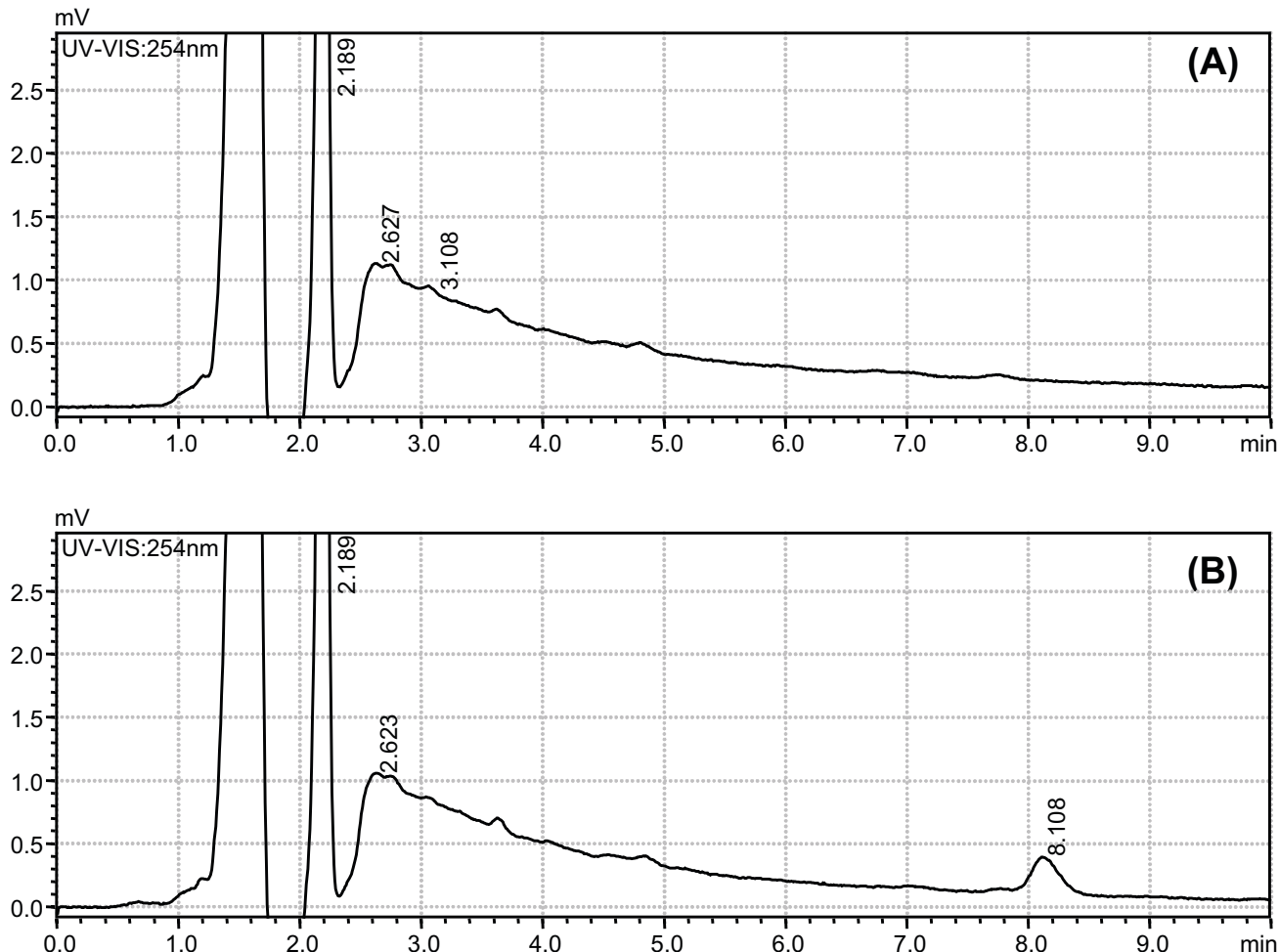

Figure 6 - Detector response in function of time in minutes. (A) Extract chromatogram obtained from the PVA free herbicide soil and (B) extract chromatogram of the same soil spiked with $50.0 \mu \mathrm{g} \mathrm{L} \mathrm{L}{ }^{-1}$ of the studied herbicide, in which: $t_{\mathrm{R}}=8$. 1: picloram.
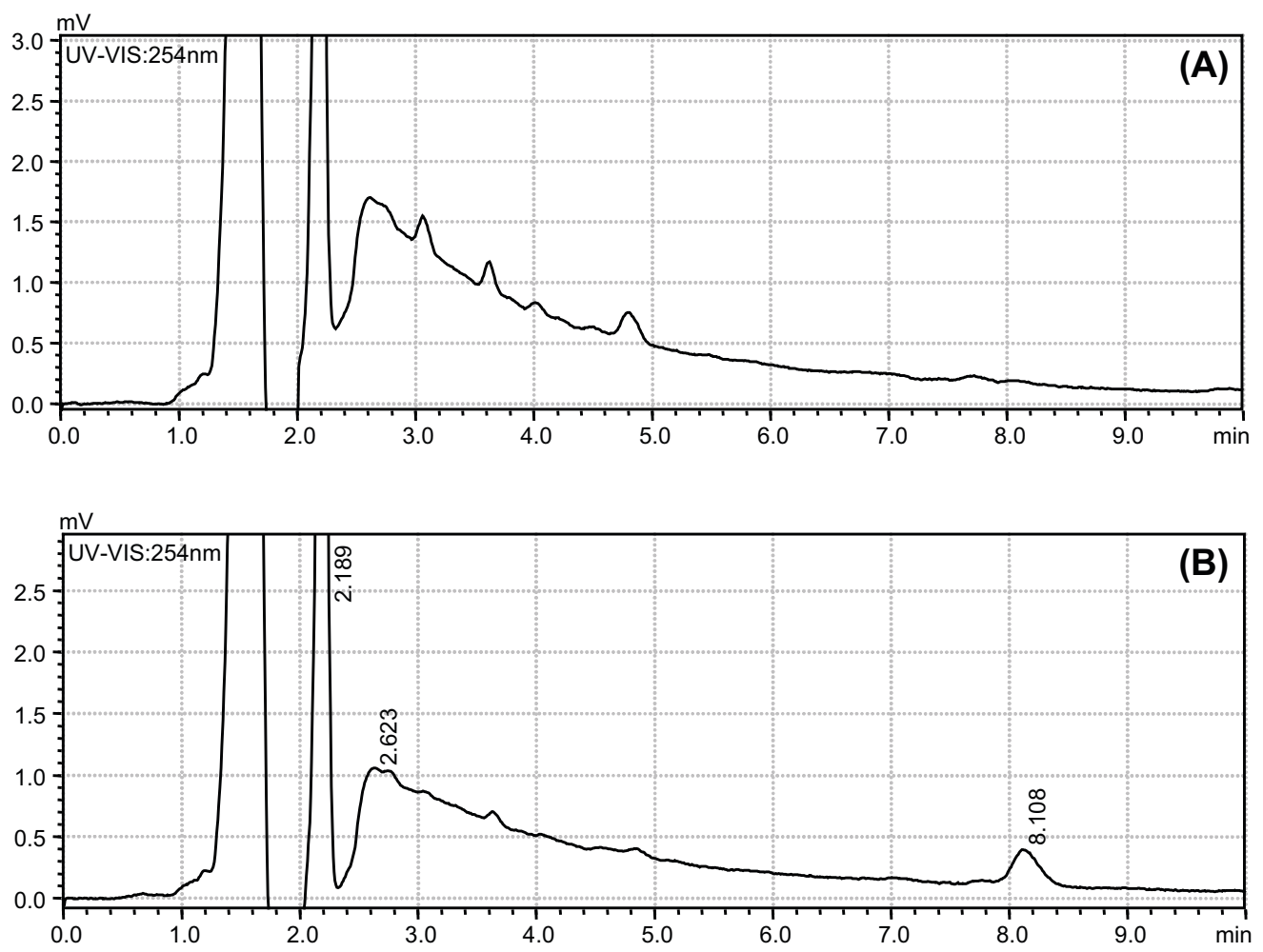

Figure 7 -Detector response in function of time in minutes. (A) extract chromatogram of LVA herbicide free soil and (B) chromatogram of the same soil spiked with $50.0 \mu \mathrm{g} \mathrm{L}-1$ of the studied herbicide in which: $t_{R}=8.1$ : picloram. 


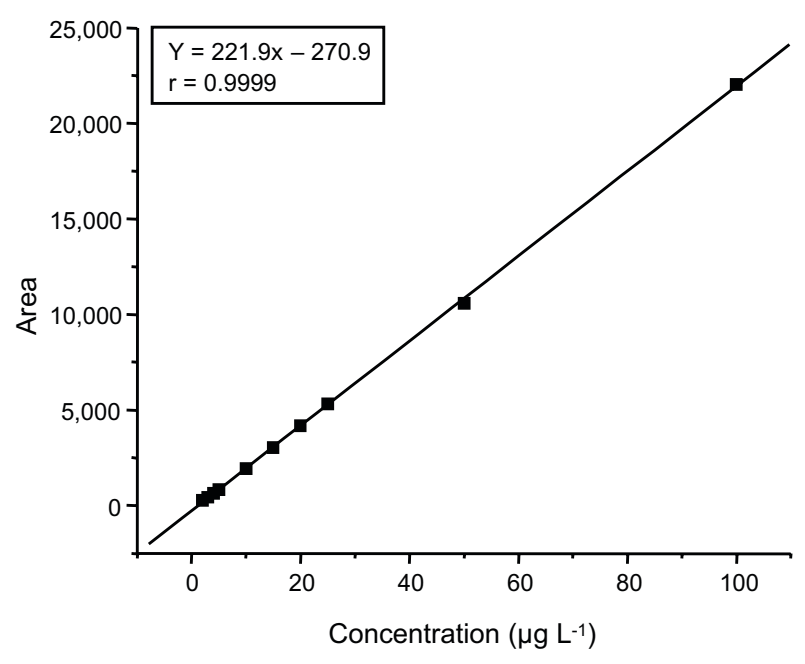

Figure 8 - Calibration curve obtained from the application of ESL technique in PVA soil samples spiked with different concentrations of picloram, to obtain the final extracts in concentrations from 1.0 to $100.0 \mu \mathrm{g} \mathrm{\textrm {L } ^ { - 1 }}$.

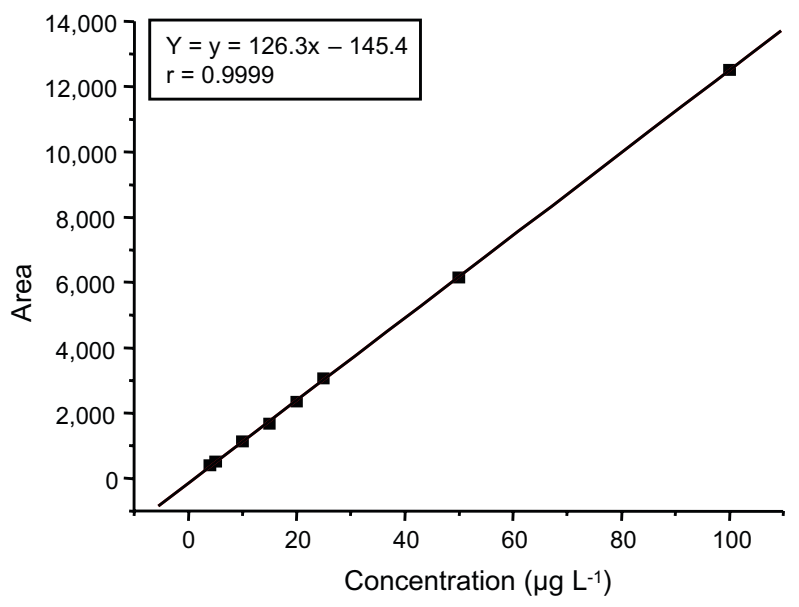

Figure 9 - Calibration curve obtained from the application of ESL technique in LVA soil samples spiked with different concentrations of picloram, to obtain the final extracts in concentrations from 1.0 to $100.0 \mu \mathrm{g} \mathrm{L} \mathrm{L}^{-1}$.

concentration range 2.0 to $100.0 \mu \mathrm{g} \mathrm{L}^{-1}$. For LVA the methodology shows linearity response in the range of 4.0 to $100.0 \mu \mathrm{g} \mathrm{L} \mathrm{L}^{-1}$.

The limit of detection (LOD) for chromatographic methods corresponds to the smallest concentration of the substance of interest that can be detected but not necessarily accurately quantified. The limit of quantification (LQ) corresponds to the lowest concentration of the substance of interest that can be accurately quantified (INMETRO, 2003).
The limits of detection and quantification were determined by the method of signalto-noise ratio, where the LD was found in reference to the concentration that gave a signal three times higher than the average noise of the device, and LQ, a signal 10 times higher than that noise, comparing with a white previously injected. This method is visual, where detectable and quantifiable concentrations substances of interest are determined visually, considering the amount of compound capable of producing an analytical signal three to ten times higher than the level of background noise (Collins et al., 1997).

Once there is no maximum residue limit (MRL) established by the National Sanitary Vigilance Agency (Anvisa) for this herbicide in soils, based on application rate, which ranges from 1 to $4 \mathrm{~L}$ per hectare of the commercial product containing $240 \mathrm{~g}$ of active ingredient, and taking into account the various possibilities of dissipation, degradation and retention of this compound in the soil, it was attempted to work with boundaries close to the device limits.

The limits of detection and quantification obtained from the extracts of the soils are presented in Table 7 .

Taking into consideration the sample mass used $(2.00 \mathrm{~g})$ and $20.0 \mathrm{~mL}$ of extraction solution, converting $\mu \mathrm{g} \mathrm{L}^{-1}$ limits of the extract in $\mu \mathrm{g} \mathrm{kg}^{-1}$ of soil, it is obtained the new LD and LQ values, shown in Table 7 .

The limits of detection and quantification obtained in this work are lower than those obtained by Krzyszowska \& Vance (1994), which demonstrates progress and improvement in the applied technique.

Precision is a general term used to evaluate the dispersion of results for the same sample (Spear, 2004). It was considered in two levels: repeatability and intermediate precision.

Repeatability is the agreement between the results of successive measurements by the same method under the same measurement conditions. It can be expressed quantitatively in terms of the characteristic results dispersion by estimating the standard deviation of seven or more repetitions (INMETRO, 2003). 
Tabela 7 - Detection (LD) and quantification (LQ) limits found by the proposed method in the studied soils, in $\mu \mathrm{g} \mathrm{L} \mathrm{and} \mu \mathrm{g} \mathrm{kg}^{-1}$

\begin{tabular}{|c|c|c|c|c|c|}
\hline Soil & $\mathrm{LD}\left(\mu \mathrm{g} \mathrm{L}^{-1}\right)$ & $\mathrm{LQ}\left(\mu \mathrm{g} \mathrm{L}^{-1}\right)$ & Soils & $\mathrm{LD}\left(\mu \mathrm{g} \mathrm{kg}^{-1}\right)$ & $\mathrm{LQ}\left(\mu \mathrm{g} \mathrm{kg}^{-1}\right)$ \\
\hline PVA & 2.0 & 6.6 & PVA & 20.0 & 66.0 \\
\hline LVA & 4.0 & 13.2 & LVA & 40.0 & 132.0 \\
\hline
\end{tabular}

The results of the coefficient of variation (CV) obtained for the soil samples vary between 2.32 and $2.69 \%$ (Table 8 ). These values demonstrate repeatability, since the coefficients of variation were below recommended levels. According Ribani et al. (2004), it is acceptable CV of $20 \%$ for complex samples.

This analytical parameter refers to variations within the same laboratory when one or more important factors are modified, as different analysts, different days or different equipment (Ribani et al., 2004). The intermediate precision of the method was verified by recovery percentages of the analyte and the corresponding coefficients of variation (CVs) taht were analyzed in three different days. Analyses were performed on the $1^{\text {st }}, 7^{\text {th }}$ and $30^{\text {th }}$ day, by the same analyst and same equipment. Analyses were done in triplicate. The results are shown in Table 9. It can be noted on this table that the coefficient of variation found for the herbicide are smaller than $20.0 \%$, indicating that the ESL method shows a good intermediate precision.

There are several ways to evaluate the accuracy of a method such as the use of reference materials, comparison of methods, and recovery experiments. In this study, it was performed a recovery test, which is based on recovery efficiency (\%R). This parameter is defined as the ratio of the amount of interest, previously added to the matrix, which is extracted and can be analyzed (INMETRO, 2003). The accuracy of a method represents the degree of agreement between the results found in an individual test and a reference value accepted as true (INMETRO, 2003).

During this analytical parameter evaluation, it was performed a recovery test, in which the extracts had concentrations of 10.0, 20.0 and $100.0 \mu \mathrm{g} \mathrm{L}^{-1}$ for PVA soil and $15.0,30.0$ and $150.0 \mu \mathrm{g} \mathrm{L}^{-1}$ for LVA soil, which are approximately 1,2 and 10 times the quantification limit.
Table 8 - Recovery percentages (\% R), standard deviation (SD) and coefficient of variation (CV) obtained after seven extractions of picloram in fortified soils, whose statements would present final concentrations equal to 10 and $20 \mu \mathrm{g} \mathrm{L}^{-1}$ for PVA and LVA soils, respectively

\begin{tabular}{|c|c|c|c|}
\hline Soil & \% R & SD & CV (\%) \\
\hline PVA & 95.94 & 2.19 & 2.32 \\
\hline LVA & 92.13 & 2.47 & 2.69 \\
\hline
\end{tabular}

Table 9 - Extraction percentage ( $\%$ R) and coefficient of variation (CV) obtained after analysis on different days by the same analyst; and analysis of fortified soil samples, which would present the final extract concentrations equal to 10 and $20 \mu \mathrm{g} \mathrm{L}^{-1}$ for PVA and LVA soils, respectively

\begin{tabular}{|c|c|c|c|c|}
\hline \multirow{2}{*}{ Soil } & $1^{\text {st }}$ Day & $7^{\text {th }}$ & $30^{\text {th }}$ & \multirow{2}{*}{$\begin{array}{l}C V \\
(\%)\end{array}$} \\
\hline & $\% \mathrm{R}$ & $\% \mathrm{R}$ & $\% \mathrm{R}$ & \\
\hline PVA & $92.6 \pm 1.4$ & $96.3 \pm 1.3$ & $92.8 \pm 1.5$ & 2.35 \\
\hline LVA & $89.6 \pm 0.6$ & $94.2 \pm 1.4$ & $90.3 \pm 1.8$ & 2.70 \\
\hline
\end{tabular}

The recovery intervals and coefficients of variation found are acceptable, taking into consideration the recovery values between 70 and $120 \%$, with coefficient of variation up to $20 \%$, and also depending on the complexity of the sample, from 50 to $120 \%$ ranging from 15\% (GARP, 1999).

Cheng (1969) proposed a colorimetric method for picloram determination in soils. The detection limit was $500 \mu \mathrm{g} \mathrm{L}^{-1}$, in other words not enough for residue analysis. Krzyszowska \& Vance (1994), in its adaptation, proposed a clean-up step to the extraction process indicated by Cheng (1969), that is to say a purification of the extracts using EFS (solid phase extraction) assisted by the use of cartridges of nonpolar adsorbent material, the $\mathrm{C}-18$, and reaching a detection limit of $10 \mu \mathrm{g} \mathrm{L}^{-1}$, a sufficient limit to the waste analysis, but included an additional step in the process where the analyte can be lost, apart 
Table 10 - Evaluation of ESL accuracy, for testing of recovery $(\% \mathrm{R})$ and coefficient of variation $(\mathrm{CV})$

\begin{tabular}{|c|c|c|c|c|c|c|}
\hline Soil & \multicolumn{6}{|c|}{ Concentration $\mu \mathrm{g} \mathrm{L}^{-1}$} \\
\hline \multirow{3}{*}{ PVA } & \multicolumn{2}{|c|}{10.0} & \multicolumn{2}{|c|}{20.0} & \multicolumn{2}{|c|}{100.0} \\
\cline { 2 - 7 } & $\% \mathrm{R}$ & $\mathrm{CV}$ & $\% \mathrm{R}$ & $\mathrm{CV}$ & $\% \mathrm{R}$ & $\mathrm{CV}$ \\
\cline { 2 - 7 } & 88.0 & 2.62 & 93.3 & 1.66 & 95.7 & 1.04 \\
\hline \multirow{3}{*}{$\mathrm{LVA}$} & \multicolumn{2}{|c|}{15.0} & \multicolumn{2}{|c|}{30.0} & \multicolumn{2}{|c|}{150.0} \\
\cline { 2 - 7 } & $\% \mathrm{R}$ & $\mathrm{CV}$ & $\% \mathrm{R}$ & $\mathrm{CV}$ & $\% \mathrm{R}$ & $\mathrm{CV}$ \\
\cline { 2 - 7 } & 86.7 & 4.08 & 89.7 & 1.99 & 91.3 & 1.20 \\
\hline
\end{tabular}

from increasing labor and consumption of organic solvents.

For this work it was optimized and validated the ESL technique for determining picloram herbicide in two Brazilian soils: Red-Yellow Acrisol and Red-Yellow Latosol. During the initial phase of the optimization technique process the major variables that influenced the efficiency of the extraction process were separately evaluated. The optimized variables were: soil-extraction solution ratio, ionic strength and extraction solution $\mathrm{pH}$, time and type of agitation.

The ESL methodology proved to be efficient for residue analysis of the studied pesticides, with percentages of recovery above $90 \%$. Besides, it had low consumption of organic solvents during the analysis and cleaner extracts, requiring no purification steps for chromatographic analysis. The parameters evaluated in the validation process - selectivity, detection limit, quantification limit, linearity, precision and accuracy - indicated that the ESL methodology is efficient for picloram residues extraction in the studied soils, with low detection and quantification limits.

Therefore, with the optimization and validation of the technique applied in this study, it was possible to reduce the steps, facilitating the process and the consumption of organic solvents during the analysis; it also managed to lower the limit of detection in extracts to $2 \mu \mathrm{g} \mathrm{L}{ }^{1}$.

\section{LITERATURE CITED}

AGÊNCIA NACIONAL DE VIGILÂNCIA SANITÁRIA ANVISA. Resolução no 899, de 29/05/2003. Guia para validação de métodos analíticos e bioanalíticos. Brasília: 2003.

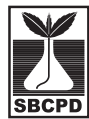

BIGGAR, J. W.; CHEUNG, M. W. Adsorption of picloram (4-amino-3, 5,6-trichloropicolinic acid) on Panoche, Ephrata, and Palouse soils: a thermodynamic approach to the adsorption mechanism. Soil Sci. Soc. Am. Proc., v. 37. p. 863-868, 1973.

BOVEY, R. W.; RICHARDSON, C. W. Organic chemicals in the environment. dissipation of clopyralid and picloram in soil and seep flow in the Blacklands of Texas. J. Environ. Qual., v. 20, n. 3, p. 528-531, 1991.

BRUNER, F.; BERLONI, A.; PALMA, P. Determination of acidic chlorinated pesticides in water: comparison of official EPA method 515.1 and liquid-solid extraction HPLC/UV and HPLC/PBMS analyses. Chromatographia, v. 43, n. 5/6, p. 279-284, 1996.

CARTER, M. R. Soil sampling and methods of analysis Saskatoon: Canadian Society of Soil Science, 1993.

CELIS, R. et al. Clay-herbicide complexes to retard picloram leaching in soil. Inter. J. Environ. Anal. Chem., v. 82, n. 8-9, p. $503-517,2002$.

CELIS, R. et al. Sorption and leaching behavior of polar aromatic acids in agricultural soils by batch and column leaching tests. Europ. J. Soil Sci., v. 56, p. 287-297, 2005.

CHENG, H. H. Extraction and colorimetric determination of picloram in soil. J. Agric. Food Chem., v. 17, n. 6, p. $1174-1175,1969$

CHENG, H. H. Picloram in soil: extraction and mechanism of adsorption. B. Environ. Contam. Toxicol., v. 6, n. 1, p. $28-33,1971$

CHEUNG, M. W.; BIGGAR, J. W. Solubility and molecular structure of 4-amino-3,5,6-trichloropicolinic acid in relation to pH and temperature. J. Agric. Food Chem., v. 22, n. 2, p. 202-206, 1974.

COLLINS, C. H.; BRAGA, G. L.; BONATO, P. S. Introdução a métodos cromatográficos. 7.ed. Campinas: Unicamp, 1997.

D'ANTONINO, L. et al. Lixiviação do picloram em Argissolo-Vermelho Amarelo e Latossolo Vermelho-Amarelo com diferentes valores de pH. Planta Daninha, v. 27, n. 3, p. 589-600, 2009.

DEMUNER, A. J. A. et al. Sorption and persistence of sorgoleone in red-yellow latossol. Quimica Nova, v. 28, n. 3, p. $451-455,2005$.

DEUBERT, K. H.; CORTE-REAL, I. Soil residues of picloram and triclopyr after selective foliar application on utility rights-of-way. J. Arboric., v. 12, p. 269-272, 1986.

Planta Daninha, Viçosa-MG, v. 29, n. 3, p. 683-696, 2011 
EMPRESA BRASILEIRA DE PESQUISA

AGROPECUÁRIA - EMBRAPA. Centro Nacional de Pesquisa de Solos. Manual de métodos de análise de solos

2.ed. Rio de Janeiro: 1997. 212 p.

FARMER, W. J.; AOCHI, Y. Picloram sorption by soils. Soil Sci. Soc. Am. Proc., v. 38, p. 418-423, 1974.

GARP, Associação grupo de analistas de resíduos de pesticidas; Manual de resíduos de pesticidas em alimentos, 1999.

HAMAKER, J. W.; GORING, C. A. I.; YOUNGSON, C.R. "Organic pesticides in environment." Washington American Chemical Society, 1968. p. 23-37. (Advances in Chemistry Series, 60)

INSTITUTO NACIONAL DE METROLOGIA INMETRO. Normalização e qualidade industrial. Orientações sobre validação de métodos de ensaios químicos. DOQ-CGCRE-008, 2003.

INOUE, M. H. et al. Critérios para avaliação do potencial de lixiviação dos herbicidas comercializados no Estado do Paraná Planta Daninha, v. 21, n. 2, p. 313-323, 2003.

KRZYSZOWSKA, A. J.; VANCE, G. F. Solid-phase extraction of dicamba and picloram from water and soil samples for HPLC analysis. J. Agric. Food. Chem., v. 42, n. 8, p. 1693-1696, 1994.

LANÇAS, F. M. Extração em fase sólida (SPE). São Carlos: Rima, 2004a. 96 p.

LAVY, T. L. et al. Long-term in situ leaching and degradation of six herbicides aged in subsoils. J. Environ. Qual., v. 25, n. 6, p. $1268-1279,1996$

LOURENCETTI, C.; MARCHI, M. R. R.; RIBEIRO, M. L. Determination of sugar cane herbicides in soil and soil treated with sugar cane vinasse by solid-phase extraction and HPLC-UV. Talanta, v. 77. p. 701-709, 2008.

McCALL, H. G. et al. Asorption and desorption of picloram, trifluralin, and paraquat by ionic and nonionic exchange resins Weed Sci., v. 20, n. 3, p. 250-255, 1972.

McKONE, C. E.; COTTERILL, E. G. Extraction of picloram residues from a sandy loam soil. B. Environ. Contam.

Toxicol., v. 11, n. 3, p. 233-237, 1974.
PAULA, R. T. Mobilidade de atrazine e ametryn em latossolo vermelho amarelo. 2007. 85 f. Dissertação (Mestrado em Agroquímica) - Universidade Federal de Viçosa, Viçosa, MG, 2007.

PIRES, W. Manual de pastagem: formação, manejo e recuperação. Viçosa, MG: Aprenda Fácil, 2006.

RIBANI, M. et al. Validação em métodos cromatográficos e eletroforéticos. Química Nova, v. 27, n. 5, p. 771-780, 2004.

RODRIGUES, B. N.; ALMEIDA, F. S. Guia de herbicidas. 5.ed. Londrina: Grafmarke, 2005.

SANTOS, L. B. O; MASINI, J. C. Determination of picloram in natural waters employing sequential injection square wave voltammetry using the hanging mercury drop electrode. Talanta, v. 72. p. 1023-1029, 2007.

SANTOS, M. V. et al. Eficácia e persistência no solo de herbicidas utilizados em pastagens. Planta Daninha, v. 24, n. 2, p. 391-398, 2006.

SILVA, A. A.; SILVA, J. F. Tópicos em manejo de plantas daninhas. Viçosa, MG: Universidade Federal de Viçosa, 2007.

TAN, L. K. et al. Determinations of clopyralid, picloram, and silvex at low concentration is soils by calcium hydroxidewater extraction and gas chromatography measurement. J. Agric. Food Chem., v. 44, n. 4, p. 1135-1143, 1996.

VOLK, V. V.; KUO, E. C. Y. Contributing report from Oregon State University to Western Regional Research Project W-82, "Pesticide Mobility and Degradation in Soil-Water Systems," presented in Denver, Colorado, Dec 2-3, 1970.

WELLS, M. J. M.; MICHAEL, J. L. Recovery of picloram and 2,4-Dichlorophenoxyacetic acid from aqueous samples by reversed-phase solid-phase extraction. Anal. Chem., v. 59, n. 13, p. $1739-1742,1987$.

WELLS, M. J. M; MICHAEL, J. L.; NEARY, D. G. Determination of picloram in soil and water by reversedphase liquid chromatography. Arch. Environ. Contam. Toxicol., v. 13. p. 231-235, 1984.

WELLS, M. J. M.; YU, L. Z. Solid-phase extraction of acidic herbicides. J. Chromatogr. A, v. 885, n. 1-2, p. 237-250, 2000. 